\title{
ANTAGONISTIC ACTION OF PYRIDOXINE TO TOXOPYRIMIDINE ON THE GROWTH OF MICE
}

\author{
KEN-ICHI TORIGOE AND TAKEO KINOSHITA \\ Department of Biological Chemistry, School of Medicine, Kumamoto \\ University, Kumamoto and Department of Biological Chemistry, \\ Jikeikai Medical College, Tokyo
}

(Received June 28, 1956)

It was reported by the authors $(1-4)$ that $\mathrm{B}_{6}$ group-vitamins had a strong atoxopyrimidine action. Watanabe and Shintani (5) proved the antagonistic action between $\mathrm{B}_{6}$ group-vitamins and toxopyrimidine ${ }^{1}$ (TXP) in rats.

In the present paper evidence will be given indicating an antagonistic action between pyridoxine and TXP on the growth of young weanling male DD mice.

\section{EXPERIMENTAL}

\section{Materials and Method}

Young weanling male DD mice were given a synthetic diet for a certain period. Mice fed with a diet containing TXP deficient in pyridoxine lost weight rapidly and died (Fig. 1, E). When pyridoxine was added to this diet, the mice recovered weight promptly (Fig. 2, curve 3).

The basal diet consisted of, in per cent, purified starch, 60 ; purified casein, 20; lard, 15 and McCollum salt mixture (No. 185), 5 . One drop of cod liver oil per day per animal was also administered. A vitaminmixture consisting of $1 \mathrm{mg}$ of thiamine hydrochloride, $0.4 \mathrm{mg}$ of riboflavin, $0.1 \mathrm{mg}$ of pyridoxine hydrochloride, $3 \mathrm{mg}$ of calcium pantothenate, $10 \mathrm{mg}$ of inositol, and $25 \mathrm{mg}$ of $p$-aminobenzoic acid was added to each $100 \mathrm{~g}$ of the basal ration. The

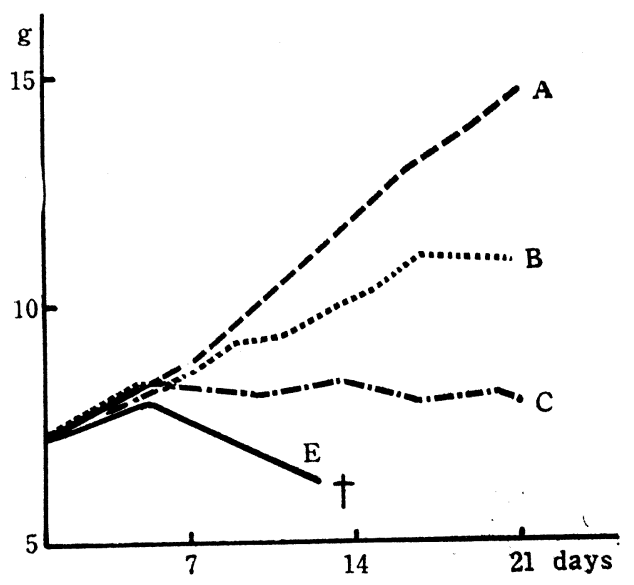

Fic. 1 Average Body-weight Curves of Young Male DD Mice fed with Diet $A, B$, $C$, and $E$

$A, 8$ mice fed with $\operatorname{diet} A ; B, 7$ mice fed with $\operatorname{diet} \mathrm{B} ; \mathrm{C}, 8$ mice fed with $\operatorname{diet} \mathrm{C}$; $\mathrm{E}, 8$ mice fed with diet $\mathrm{E}$; $\dagger$, all the animals of group $E$ died in 13-15 days.

\footnotetext{
${ }^{1}$ 2-Methyl-6-amino-5-hydroxymethylpyrimidine
} 


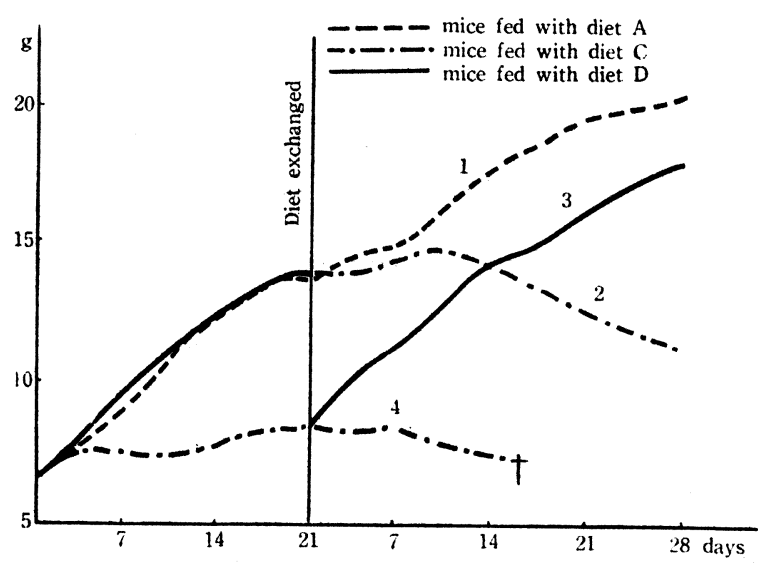

Fia. 2 Average Body-weight Curves of Young Male DD Mice Fed with Diets $A, C$, and D

1, 7 mice fed with diet A; 2, 7 mice fed with diet $D$ followed by $C ; 3,7$ mice fed with diet $C$ followed by D; 4,2 mice fed with diet $C ; \dagger$, all the animals of this group died in 37 days. animals received each of the following 5 kinds of diet;

Diet $A$, the basal diet alone.

Diet $B$, the basal diet minus pyridoxine.

Diet $\mathrm{C}$, the basal diet containing $5 \mathrm{mg}$ of TXP per $100 \mathrm{~g}$.

Diet $D$, the basal diet containing both $5 \mathrm{mg}$ of TXP and $6.6 \mathrm{mg}$ of pyridoxine per $100 \mathrm{~g}$.

Diet $E$, the basal diet plus $5 \mathrm{mg}$ of TXP per $100 \mathrm{~g}$ minus pyridoxine.

\section{Results}

1. Effect of TXP on the Growth of Mice.

The animals were fed with diets $A, B, C$, and $E$, respectively, for 21 days. Mice fed with diet A continued to grow normally. Mice fed with diet $E$ lost body weight rapidly, manifesting the symptoms resembling those of vitamin $\mathrm{B}_{\boldsymbol{6}}$ deficiency within $7-10$ days and died within $13-15$ days (Fig. 1, E). The clinical symptoms of the deficiency were lifelessness, loss of hair especially around the nostril, on the ventral side of both the neck, and abdomen, bristling up or lying of hair, reddishness and swelling of the hind legs, loss of glossiness and drying of the tail skin, etc. as given in Table I.

In mice fed with diet $C$, increase in body weight was considerably suppressed, and symptoms of vitamin $B_{B}$ deficiency appeared, but not a mouse

TABLE I

Clinical Symptoms of the Deficiency in Test Animals

Symptoms

Bristling up or lying of hair

Dermatitis

Ears covered by a scaly encrustation

Loss of hair in encrusted areas over the forehead

Adhesion of the eye lids

Loss of hair around the nostril

Loss of hair on the ventral side of the neck

Loss of hair of the shoulders

Loss of hair of the abdomen

Loss of glossiness and drying of the tail skin

Necrotic tails

Reddishness and swelling of the hind legs

Paralysis in the hind legs

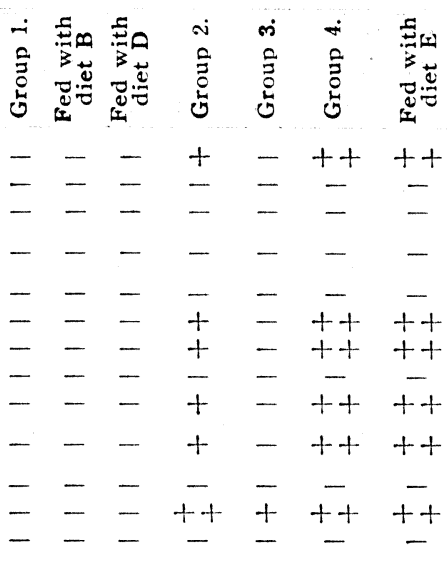

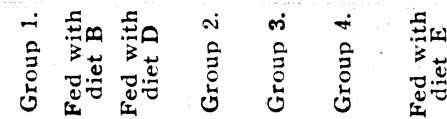

$$
\begin{aligned}
& --\ldots++++ \\
& \text { - - - - - } \\
& \text { - }- \text { - }- \text { - }- \\
& =\overline{-} \overline{-} \overline{+}+\overline{+} \\
& --+-++++ \\
& =-\overline{-}-\bar{t}+\overline{+} \\
& --\infty-+++t \\
& =\overline{-}-\bar{t}+\overline{+}+\overline{+}
\end{aligned}
$$


died in 21 days during the experiment (Fig. 1, C).

In mice fed with diet $B$, increase in body weight was stopped within 18 days, but no apparent symptoms of deficiency were seen till the 21 st day (Fig. 1, B).

2. Antagonistic Action of Pyridoxine to TXP on the Growth of Mice.

In the next series of experiments, the animals were fed with $\operatorname{diets} A, C$, and $D$, respectively, for 21 days. Mice fed with diet $D$ showed neither loss in weight nor deficiency symptoms as shown in Fig. 2.

Then, the diets of the group fed with diet $C$ or $D$ were exchanged after 21 days, and the second diets were given for 28 days as follows: Mice fed with diet $A$ were given the same diet (Group 1 ); mice fed with diet $D$ were switched to diet $C$ (Group 2); mice first fed with diet $C$ were divided into 2 groups : one group received then diet $D$ (Group 3 ), and another group successively received diet $C$ (Group 4). Mice in Group 2 showed a rapid loss in weight, and symptoms of deficiency appeared within 15-20 days (Fig. 2, curve 2). Mice in Group 3 showed a very rapid restoration of lost weight, and deficiency symptoms disappeared in 7 days after the change in diet (Fig. 2, curve 3). On the contrary, mice in Group 4 died in 37 days (Fig. 2, curve 4).

\section{SUMMARY}

In mice reared on a basal ration containing $5 \mathrm{mg}$ of TXP per $100 \mathrm{~g}$, increase in body weight was considerably suppressed.

When the animals were fed with vitamin $B_{6}$ deficient diet containing TXP, they gradually lost weight and died within 13-15 days.

The symptoms of vitamin $B_{6}$ deficiency could be prohibited to some extent by administering the basal ration containing $0.1 \mathrm{mg}$ pyridoxine per $100 \mathrm{~g}$ but not sufficient. When basal ration containing $6.6 \mathrm{mg}$ of pyridoxine per $100 \mathrm{~g}$ was given, the weight loss and vitamin $B_{6}$ deficiency symptoms caused by TXP were thoroughly prevented, and the animals manifesting the symptoms recovered.

\section{ACKNOWLEDGEMENT}

The authors wish to thank Professor Katashi Makino for his kind guidance, and are indebted to Dr. Taizo Matsukawa, Research haboratory, Takeda Pharmaceutical Industries Ltd., for supplying a sample of 2 methy 16 amino 5 hydroxymethylpyrimidine.

This work was supported by both a grant for Scientific Research of the Ministry of Education and that of the Japan Vitamin B Committee.

\section{REFERENCES}

1. Makino, K., Kinoshita, T., Aramaki, Y., and Shintani, S., Nature 174, 275 (1954).

2. Makino, K., Kinoshita, T., Aramaki, Y., and Shintani, S., Vitamins 7, 670 (1954).

3. Makino, K.,and Kinoshita, T., ibid. 8, 28 (1955).

4. Makino, K., and Kinoshita, T., J. Vitaminol. 1, 14 (1955).

5. Watanabe, A., and Shintani, S., Vitamins 8, 517 (1955). 